\title{
Fallecimiento de un antiguo delegado del CICR
}

Apena al CICR el fallecimiento del Dr. Jean-Maurice Rubli, uno de sus antiguos delegados, que dio pruebas de constante y denodada entrega a la causa humanitaria.

El Dr. Rubli efectuó, durante la segunda guerra mundial, numerosas misiones: visitó a prisioneros de guerra y a internados civiles en Alemania, Bélgica, Países Bajos y Francia. En ese mismo período, formó parte de comisiones médicas mixtas en Alemania, Estados Unidos y Canadá. Tras haber practicado la medicina en Zurich, se encargó de realizar nuevas misiones, a partir de 1953, en Kenia, Reino Unido, Jordania, Yemen y Arabia Saudita. Más tarde, se trasladó a diferentes países de África y de Asia; en 1970 viajó a Extremo Oriente.

No escatimó el Dr. Rubli sus energías ni su dedicación al servicio de la Cruz Roja y el CICR le recordará con fidelidad y gratitud.

\section{Nueva publicación del CICR}

El CICR reproduce, en un folleto de 28 páginas, en francés, inglés y español, el estudio que publicó la Revista Internacional, en su número de septiembre pasado, acerca de los trabajos del tercer período de sesiones de la Conferencia Diplómatica. Puede adquirirse este opúsculo, por 2.- francos suizos, dirigiéndose al servicio de publicaciones del CICR. 